\title{
STUDIES OF BONE OF PATIENTS WITH HYPERPARATHYDROIDISM BY MEANS OF PHOSPHATE EXCHANGE EXPERIMENTS IN VITRO AND QUANTITATIVE MICRORADIOGRAPHY *
}

\author{
By D. SMEENK \\ (From the Department of Clinical Endocrinology and Diseases of Metabolism, University \\ Hospital, Leiden, Holland)
}

(Submitted for publication July 6, 1959; accepted September 30, 1960)

The history of the interpretation of osteitis fibrosa cystica generalisata as it was described in 1891 by von Recklinghausen (1) explains why the skeletal abnormalities were for so long considered to be the focal point of the clinical concept "hyperparathyroidism." During the 1930's, however, it was observed that many patients with hyperparathyroidism showed no bone abnormalities on either histological or roentgenological examination (2). Recent publications show that only in one-third of the patients with hyperparathyroidism can skeletal deviations be demonstrated roentgenologically (3). This is remarkable, since a direct effect of parathormone on the skeleton has been established. It was demonstrated by treating nephrectomized rats with parathyroid extract (4), and by implanting parathyroid tissue under the skull of the mouse (5). Finally, it was shown that a cell-free parathyroid extract has a direct effect on tissue cultures of the parietal bone of mouse embryos and this by a reinforcement of the osteoclastic bone resorption (6).

The discrepancy between the clinical data and the pathophysiology of hyperparathyroidism might be explained by the assumption that the accelerated bone destruction caused by the hormone of the parathyroid gland is compensated for by an increase in bone production. If this hypothesis is correct, on the average, the bone of patients with hyperparathyroidism would be younger than bone of normal individuals of the same age. Evidence which supports this assumption has been found in animal experiments by using qualitative microradiography (7).

Using autoradiography, Engfeldt and Hjertquist (8) showed in 1954 that radioactive labeled phosphate is taken up in bone from a surrounding fluid, especially in young structures, and such

* This research was supported by grants from the National Health Organization T. N. O., The Hague. uptake occurs in the same regions in viv'o as in dead bone in vitro. This observation suggests that the uptake of phosphate from a solution by dead bone in vitro could be used as a measure of the ratio between the amounts of young bone and old bone present in the sample. By young bone is meant newly-formed bone; by old bone is meant older osteons and fragments of older bone. Since the uptake of phosphate from a solution by dead bone under certain conditions is primarily an exchange reaction, labeling of the phosphate of the incubation medium is necessary to follow the uptake and release of phosphate from the bone.

A method (9) for a phosphate "exchange" experiment in vitro was modified for the purpose of the present study, in such a way as to make its application to a clinical problem possible. The word, "exchange," is placed between quotation marks because there is a slight loss of phosphate from the incubation medium under the conditions used in our experiments.

The use of microradiography makes it possible to measure the mineral content of extremely small bone samples (10). Because of the likelihood of a fixed relationship between the mineral content and the "age" of bone (see Discussion), the investigation of the mineral content of bone from hyperparathyroid patients is important.

The studies to be described in this paper were performed in order to examine whether the mean age of bone from patients with hyperparathyroidism, as determined by the phosphate exchange capacity in vitro and by estimation of the mineral content per volume by microradiography, is consistent with the hypothesis that increased bone formation occurs in bone from these patients. The present report comprises the study of the bone of 17 patients with hyperparathyroidism, of 17 control individuals, and of 5 patients with hypercalcemia not caused by hyperparathyroidism, by a 
phosphate exchange test in vitro and by quantitative microradiography. Clinical data on the 17 patients with hyperparathyroidism are given in Table I.

The influence of the age of the individual on the phosphate exchange of the bone was investigated in a great number of bone specimens taken postmortem.

\section{EXPERIMENTAL METHODS AND RESULTS}

\section{A phosphate "exchange" test with powdered bone in vitro}

\section{A. Method}

The following technique was used in our studies. The bone specimen was taken by bone biopsy from the iliac crest (11), powdered and stored in 96 per cent ethanol for 24 hours. Fat and water were extracted with four 1-hour treatments, one with 96 per cent alcohol, one with absolute alcohol, and two with ether. The bone powder was then dried in vacuo and passed through a sieve with a pore diameter of $100 \mu$. Bone too coarse to pass through the sieve was reground in a mortar and then sifted. Duplicate samples of this powder weighing $10 \mathrm{mg}$ each were put into round-bottom test tubes, $2.5 \mathrm{~cm}$ in diameter, and $4 \mathrm{ml}$ of an incubation medium was added. This was a $0.005 \mathrm{M}$ solution of $\mathrm{KH}_{2} \mathrm{PO}_{4}$ and $\mathrm{Na}_{2} \mathrm{HPO}_{4}$ with a $\mathrm{pH}$ of 7.3, labeled with radioactive phosphate $(1 \mathrm{ml}$ contained $2 \cdot 10^{-2} \mu \mathrm{c}$ ).

It should be noted that the phosphate concentration of the incubation medium $(0.005 \mathrm{M})$ is higher than that of the blood plasma. Its total ion concentration, however, is lower than that of blood plasma.

The bone powder was incubated with the labeled phosphate solution for 24 hours in a Dubnoff apparatus at $37^{\circ} \mathrm{C}$ and shaken at a rate of 120 per minute and an excursion of $6 \mathrm{~cm}$. After this incubation period, the bone powder and the fluid were separated by centrifugation $(2,500 \mathrm{rpm}, 1,300 \times \mathrm{G})$, and the supernatant was isolated. The bone powder was washed with $10 \mathrm{ml}$ of distilled water, centrifuged for 10 minutes, and the supernatant combined with the supernatant from the first centrifugation, giving $14 \mathrm{ml}$ of fluid. The bone powder was dissolved by boiling in $2 \mathrm{ml}$ of $3 \mathrm{~N}$ hydrochloric acid, after which $12 \mathrm{ml}$ of distilled water was added. The radioactivity of both the fluid obtained from the phosphate solution and that from the bone powder was measured in a Geiger-Müller tube designed for liquid counting (Veall tube, 20th Century Elec., type M 6). The phosphate content of both solutions was then determined. The percentage of bone phosphate involved in the "exchange" reaction during 24 hours of incubation is calculated from these data.

The exact percentage is calculated as a percentage of the value found in a standard bone sample, which is included in each experiment. This last value will be referred to as the relative percentage. The following equation was used for the calculation:

$$
x=\frac{b c}{d a f} \times 100,
$$

where $\mathrm{x}=$ relative "exchange" percentage, $\mathrm{a}=$ total phosphorus content of bone sample, $b=$ phosphorus content of incubation solution, $\mathrm{c}=$ counts per minute of incubation solution, $d=$ counts per minute of "bone," $f=$ "exchange" percentage of standard bone powder.

Bone powder made in great quantity from autopsy material was used as the standard. It was stored dry at $0^{\circ}$ C. A standard was used because variations in results caused by small variations have the same effect on the standard as on the bone being investigated. The use of a standard therefore reduces the experimental error. The "exchange percentage" of the standard averaged 26.6 per cent.

Evaluation of the experimental error. A series of experiments was performed in order to evaluate the size of the experimental error. It was found that the standard deviation of the variation between duplicate samples ranged between 4 and 5 for a mean of 100 per cent. No increase in this standard deviation was found when du. plicate samples of bone were taken from different points of the ventral part of the iliac crest. The same standard deviation was found when $2.5 \mathrm{mg}$ of bone powder was used.

Preliminary experiments gave the impression that the percentage of exchange is slightly influenced by the concentration of phosphate in the incubation medium and by the grain size of the bone powder (12). Therefore, great care was taken to standardize these variables. It was found that the percentage of exchange of the bone from controls was not influenced when the bone sample was taken shortly after death or 24 hours postmortem.

Incubation time. To choose an optimal incubation period, the "exchange" reaction was followed for a total of 96 hours in bone samples with various "exchange" percentages (Figure 1).

The curves show that the difference in "exchange" of the samples from a patient with myxedema and the calf from the standard shows practically no change after 24 hours, the percentages for the calf, the standard, and the myxedema patient after 24 hours of incubation being 90 , 100 and 130, and after 96 hours, 113, 128 and 157, respectively. A 24 hour incubation period was therefore chosen for this method. ${ }^{1}$ It seems probable that differences between bone from normal individuals and from patients with bone disease can be most easily distinguished by means of an "exchange" test when the reactions studied are those which take place at the surface of the crystal. It does not seem obvious that in vitro recrystallization in dead bone (9), which causes the last and very slow-moving phase of the "exchange," will differ to any appreciable extent in different kinds of bone, although this possibility must be considered. Therefore,

1 The amount of bone powder available made it impossible to do more than one test in duplicate although we had to choose one standard incubation time. 


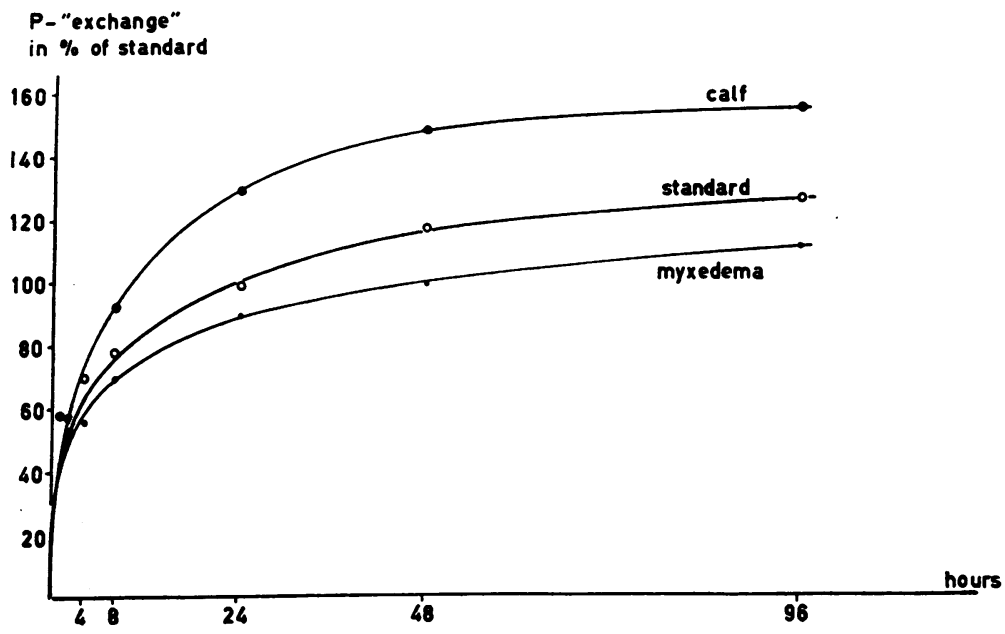

Fig. 1. The relation between incubation time and phosphate "exCHANGE" IN BONE POWDER WITH A LOW, NORMAL, AND HIGH "EXCHANGE."

the choice of 24 hours as incubation period seems justified on theoretical grounds also.

\section{B. Results}

Effect of the age of the individual on the phosphate "exchange" of bone. Bone was obtained postmortem from a large group of individuals without bone disease and the percentage of phosphate "exchange" was measured. The results are given graphically in Figure 2. As can be seen from the graph, the phosphate "exchange" of the bone has an inverse correlation with the age of the individual. Because the shape of the curve which indicates the relationship between age and phosphate "exchange" was not easy to read from the points, it is difficult to supply a statistical calculation of the material. We have used an approximation, dividing the material into age groups which reflect the three periods of life: the growth period between 0 and 20 years, the adult period between 20 and 60 years, and the period of old age, 60 years and over.

TABLE I

Clinical data of 17 patients with hyperparathyroidism

\begin{tabular}{|c|c|c|c|c|c|c|c|c|c|c|c|c|}
\hline $\begin{array}{l}\text { Patient } \\
\text { no. }\end{array}$ & Age & Sex & $\begin{array}{l}\text { Dura- } \\
\text { tion* }\end{array}$ & Systems affected & $\underset{\mathrm{Ca}}{\text { Serum }}$ & $\underset{\mathrm{P}}{\text { Serum }}$ & phosph. & $\begin{array}{l}\text { Urine } \\
\text { Ca† }\end{array}$ & $\begin{array}{l}\text { Renal } \\
\text { func- } \\
\text { tion } \ddagger\end{array}$ & X-rayst & $\begin{array}{c}\text { Bone } \\
\text { histol- } \\
\text { ogy } \ddagger\end{array}$ & Surgery $\S$ \\
\hline & yrs & & $y r s$ & & \multicolumn{2}{|c|}{$m g \%$} & $\begin{array}{l}\text { Bodan- } \\
\text { sky } U\end{array}$ & $\mathrm{mg} / 24 \mathrm{hrs}$ & & & & \\
\hline $\begin{array}{l}1 \\
2 \\
3 \\
4 \\
4 \\
5 \\
6 \\
7 \\
8 \\
9\end{array}$ & $\begin{array}{l}19 \\
19 \\
19 \\
31 \\
31 \\
35 \\
40 \\
41 \\
52\end{array}$ & $\begin{array}{l}\mathbf{M} \\
\mathbf{M} \\
\mathbf{M} \\
\mathbf{M} \\
\mathbf{M} \\
\mathbf{M} \\
\mathbf{F} \\
\mathbf{F} \\
\mathbf{F}\end{array}$ & $\begin{array}{r}\frac{1}{3} \\
3 \\
\frac{1}{3} \\
8 \\
8 \\
10 \\
9 \\
8 \\
3 \\
\frac{1}{2}\end{array}$ & $\begin{array}{l}\text { Bone } \\
\text { Urogenital } \\
\text { Gastro intestinal } \\
\text { Urogenital } \\
\text { Urogenital } \\
\text { Urogenital } \\
\text { Urogenital } \\
\text { Urogenital } \\
\text { Bone and uro- } \\
\text { genital }\end{array}$ & $\begin{array}{l}16 \\
14 \\
16 \\
13 \\
14.2 \\
14 \\
14 \\
12 \\
12\end{array}$ & $\begin{array}{l}2.2 \\
2.1 \\
1.6 \\
2.2 \\
2.4 \\
2.1 \\
3 \\
2 \\
2\end{array}$ & $\begin{array}{c}16 \\
4.9 \\
4.2 \\
4.1 \\
3.0 \\
6.9 \\
5.9 \\
3 \\
11\end{array}$ & $\begin{array}{l}500 \\
260 \\
300 \\
320 \\
240 \\
350 \\
380 \\
201 \\
500\end{array}$ & $\begin{array}{l}\bar{t} \\
\frac{ \pm}{t} \\
\bar{z} \\
\bar{t}\end{array}$ & $\begin{array}{l}\frac{+}{?} \\
\frac{-}{-} \\
= \\
+\end{array}$ & $\begin{array}{l}\bar{z} \\
\bar{z} \\
\overline{ \pm} \\
\bar{z}\end{array}$ & $\begin{array}{l}+ \\
+ \\
\frac{+}{+} \\
+ \\
+ \\
+\end{array}$ \\
\hline $\begin{array}{l}10 \\
11 \\
12 \\
13 \\
14\end{array}$ & $\begin{array}{l}59 \\
59 \\
60 \\
61 \\
61\end{array}$ & $\begin{array}{l}F \\
F \\
F \\
M \\
M\end{array}$ & $\begin{array}{l}4 \\
6 \\
6 \\
6 \\
4\end{array}$ & $\begin{array}{l}\text { Urogenital } \\
\text { Urogenital } \\
\text { Urogenital } \\
\text { Urogenital } \\
\text { Urogenital and } \\
\text { bone }\end{array}$ & $\begin{array}{l}14 \\
12 \\
11.7 \\
11.5 \\
13.4\end{array}$ & $\begin{array}{l}2.3 \\
3 \\
2.5 \\
2 \\
2.6\end{array}$ & $\begin{array}{r}5.7 \\
8.0 \\
3.4 \\
5.5 \\
15\end{array}$ & $\begin{array}{l}600 \\
270 \\
280 \\
110 \\
600\end{array}$ & 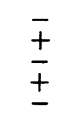 & $\begin{array}{l}\bar{z} \\
\bar{t}\end{array}$ & $\begin{array}{l}\bar{z} \\
\bar{z}\end{array}$ & $\begin{array}{l}+ \\
+ \\
+ \\
+\end{array}$ \\
\hline 15 & 66 & $\mathbf{F}$ & 6 & $\begin{array}{l}\text { Gastro intestinal, } \\
\text { bone and uro- } \\
\text { genital }\end{array}$ & 13 & 5 & 21 & 100 & + & + & + & + \\
\hline $\begin{array}{l}16 \\
17\end{array}$ & $\begin{array}{l}73 \\
74\end{array}$ & $\underset{\mathbf{F}}{\mathbf{M}}$ & 3 & $\begin{array}{l}\text { Urogenital } \\
\text { Urogenital, epulis }\end{array}$ & $\begin{array}{l}14.9 \\
12.5\end{array}$ & $\begin{array}{l}4.4 \\
2.1\end{array}$ & $\begin{array}{l}7.3 \\
7.5\end{array}$ & $\begin{array}{r}300 \\
70\end{array}$ & + & \pm & $\overline{-}$ & + \\
\hline
\end{tabular}

* Expressed as an approximation of duration of illness.

t On low calcium diet.

$\neq+$ Means abnormal; - means normal.

$\$+$ Means successful treatment; - means unsuccessful treatment. 


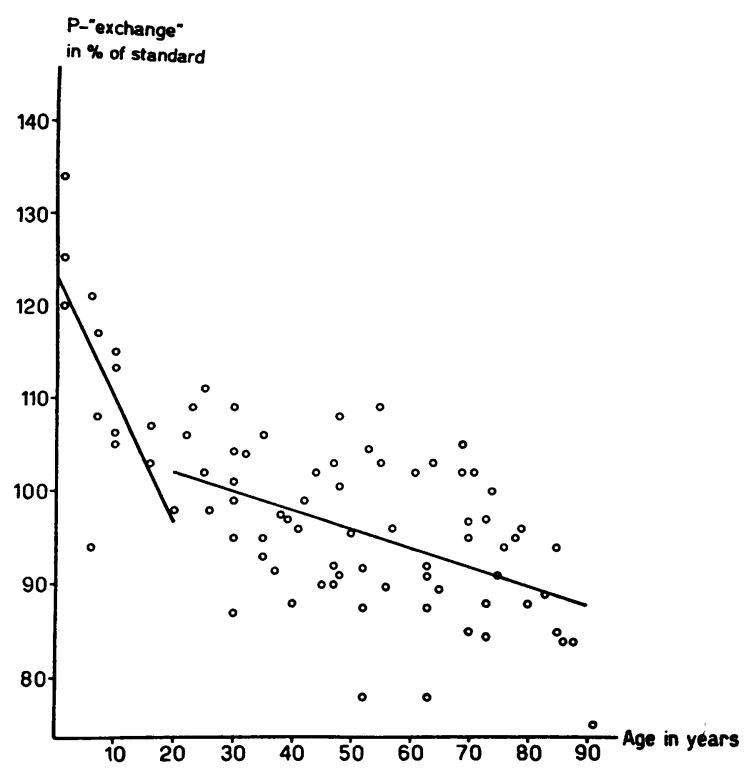

Fig. 2. Relation between age of the individual and PHOSPHATE "EXCHANGE" OF BONE IN MAN.

The linear regression coefficients were calculated for these three groups. Since the regression coefficient of the group between 20 and 60 years of age and that of 60 years and over did not differ significantly, in a second calculation of the material a division into two groups was used, one varying between 0 and 20 years, and the other comprising those over 20 years. These regression equations are:

$$
\begin{aligned}
& y=123-1.3 \times(0 \text { to } 20 \text { group }) \\
& y=106-0.2 \times(20 \text { to } 90 \text { group }) .
\end{aligned}
$$

The regression coefficient, -1.3 , differs significantly from zero $(p<0.001)$, as does that of $-0.2(p<0.01)$. The regression of the group between 0 and 20 years of age and of those over 20 years differs significantly $(p=0.001)$. The correlation coefficients of both groups are, respectively, $-0.73(\mathrm{p}<0.01)$ and $-0.49(\mathrm{p}<$ 0.001 ). Especially in very young individuals the influence of age is striking. The inverse correlation with age was also shown by an animal experiment. At the start of the experiment five animals from a group of 50 six-week-old male rats (Great Wistar) were killed. This was repeated at six-week intervals for six months, and thereafter every three months. The femora were cleaned and divided into fifths. The end parts were combined to form one sample and the cen- tral three-fifths formed the second sample. Bone powder was prepared from these samples and tested for phosphate "exchange." Five samples were used in each test and a mean value calculated. In Figure 3 the results are plotted against the age of the animals. An inverse correlation is seen between the phosphate "exchange" by the bone and the age of the test animals.

Hyperparathyroidism. The phosphate "exchange" capacity was studied in bone tissue from 17 patients suffering from hyperparathyroidism. The clinical data concerning these patients are presented in Table I. Material from 17 controls was also studied (Table II).

TABLE II

The phosphate "exchange" of bone from 17 patients with

\begin{tabular}{|c|c|c|c|c|}
\hline \multirow{3}{*}{$\begin{array}{c}\text { Subject } \\
\text { no. }\end{array}$} & \multicolumn{4}{|c|}{ Hyperparathyroidism } \\
\hline & \multirow[b]{2}{*}{ Age } & \multirow[b]{2}{*}{ Sex } & \multicolumn{2}{|c|}{ Phosphate exchange } \\
\hline & & & Abs. & Rel. \\
\hline & yrs & & $\%$ & $\%$ \\
\hline 1 & 19 & M & 44.6 & 140.3 \\
\hline 2 & 19 & $\mathbf{M}$ & 39.2 & 134.0 \\
\hline 3 & 19 & $\mathrm{M}$ & 41.2 & 141.0 \\
\hline 4 & 31 & $\mathrm{M}$ & 34.7 & 118.0 \\
\hline 5 & 31 & $\mathrm{M}$ & 31.8 & 117.0 \\
\hline 6 & 35 & $\mathrm{M}$ & 37.3 & 123.0 \\
\hline 7 & 40 & $\mathrm{~F}$ & 38.6 & 129.0 \\
\hline 8 & 41 & $\mathrm{~F}$ & 36.2 & 126.0 \\
\hline 9 & 52 & $\mathrm{~F}$ & 37.3 & 127.0 \\
\hline 10 & 50 & $\mathrm{~F}$ & 33.1 & 111.0 \\
\hline 11 & 59 & $\mathrm{~F}$ & 33.7 & 118.0 \\
\hline 12 & 60 & $\mathrm{~F}$ & 29.3 & 99.0 \\
\hline 13 & 61 & $\mathrm{M}$ & 32.9 & 115.0 \\
\hline 14 & 61 & $\mathrm{M}$ & 28.2 & 95.0 \\
\hline 15 & 66 & $\mathrm{~F}$ & 39.6 & 136.0 \\
\hline 16 & 73 & $\mathrm{M}$ & 39.6 & 134.0 \\
\hline 17 & 74 & $\mathrm{~F}$ & 38.4 & 131.0 \\
\hline Mean & 47 & & & 123.2 \\
\hline & & & & 13.2 \\
\hline & \multicolumn{3}{|c|}{ Controls } & \\
\hline 1 & 12 & M & 32.0 & 108.8 \\
\hline 2 & 22 & M & 29.7 & 106.0 \\
\hline 3 & 23 & $\mathrm{M}$ & 30.3 & 108.0 \\
\hline 4 & 25 & $\mathrm{M}$ & 28.7 & 102.0 \\
\hline 5 & 30 & $\mathrm{~F}$ & 27.9 & 95.0 \\
\hline 6 & 35 & $\mathrm{M}$ & 29.0 & 106.0 \\
\hline 7 & 41 & $\mathrm{~F}$ & 26.2 & 96.0 \\
\hline 8 & 42 & $\mathrm{~F}$ & 30.1 & 99.5 \\
\hline 9 & 47 & $\mathrm{~F}$ & 23.0 & 92.0 \\
\hline 10 & 47 & $\mathrm{M}$ & w. & 103.0 \\
\hline 11 & 47 & $\mathrm{M}$ & 26.6 & 90.0 \\
\hline 12 & 48 & $\mathrm{~F}$ & 29.6 & 100.5 \\
\hline 13 & 52 & $\mathrm{M}$ & 29.4 & 93.0 \\
\hline 14 & 57 & $\mathrm{~F}$ & 26.2 & 96.5 \\
\hline 15 & 69 & $\mathrm{M}$ & 30.1 & 102.5 \\
\hline 16 & 74 & $\mathrm{~F}$ & 31.7 & 100.9 \\
\hline 17 & 87 & $\mathrm{M}$ & 26.4 & 84.0 \\
\hline \multirow{2}{*}{$\begin{array}{l}\text { Mean } \\
\text { SD }\end{array}$} & 45 & & & 90.0 \\
\hline & & & & 6.9 \\
\hline
\end{tabular}
hyperparathyroidism and from 17 controls 


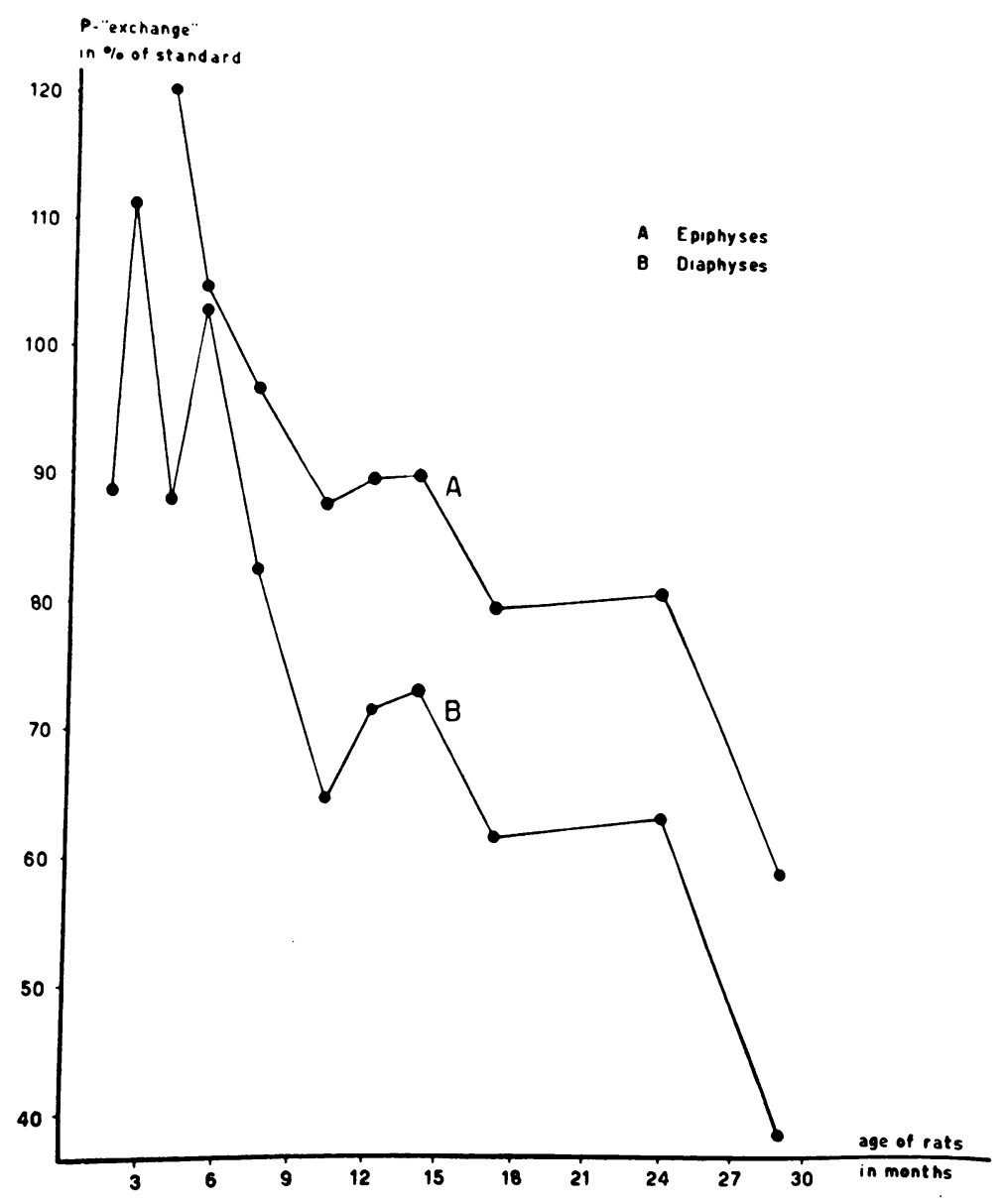

Fig. 3. Relation between age of male rats and phosphate "exCHANGE" OF BONE. Each point represents the mean of five animals. The 29 month age group consists of the two remaining animals.

The average "exchange" percentage in the hyperparathyroid group was $123.3 \pm 13.2$ per cent of the standard, while in the control group this was $99 \pm 6.9$ per cent. This difference is highly significant $(\mathrm{p}<0.001)$. The data for both groups are shown graphically in Figure 4. Application of the $\chi^{2}$ test shows that the results from Patients 10,12 , and 14 fall within the control group, while Patient 13 had a borderline value. The data for the remaining 13 patients can be considered as not belonging to the control group.

It was found that a small loss of phosphate from the incubation medium occurs during the incubation process (Table III). These data show that the mean amount of phosphate which is lost is larger in the group of patients $(36 \mu \mathrm{g})$ than in the controls $(7 \mu \mathrm{g})$. If we assume that the phosphate which is lost from the medium is shifted to the bone, it can be calculated that a considerable part of the increase of exchange in the bone of patients with hyperparathyroidism is due to an increased uptake of phosphate.

Samples of bone were taken for phosphate "exchange" measurements from two patients with hyperparathyroidism (Patients 1 and 15 in Table I) after successful surgical treatment of their disease. The results are given in Table IV. At the time of the second biopsy, Patient 1 was in good health for three years after the operation. Patient 15 died a year after the operation as a result of a kidney insufficiency. The biopsy was performed postmortem. The second samples showed for both patients a sharp drop in the phosphate "exchange" in comparison with the first samples.

A determination was also made of the phos- 


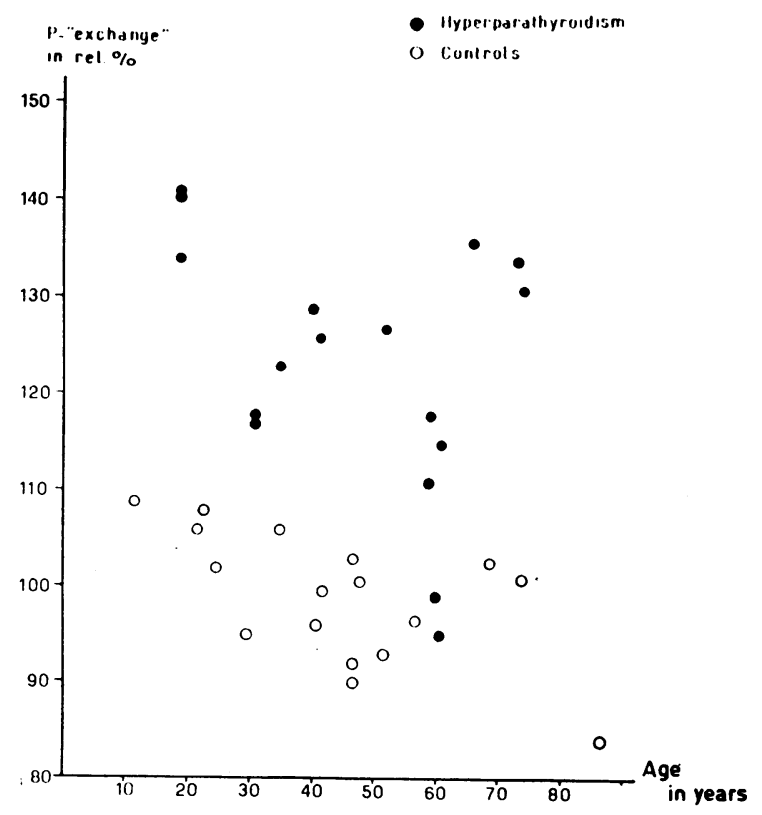

Fig. 4. Comparison of phosphate "exchange" PerCENTAGE OF BONE FROM PATIENTS WITH HYPERPARATHYROIDISM WITH THAT OF CONTROLS. The exchange is expressed in a percentage of a standard.

TABLE III

Shift of phosphate from incubation medium to bone in the phosphate "exchange" tests for 17 patients with hyperparathyroidism and for 17 controls

\begin{tabular}{ccc}
\hline \hline $\begin{array}{c}\text { Subject } \\
\text { no. }\end{array}$ & $\begin{array}{c}\text { Hyperpara- } \\
\text { thyroidism } \\
\text { Difference* }\end{array}$ & $\begin{array}{c}\text { Controls } \\
\text { Difference* }\end{array}$ \\
\hline & $\mu g$ & $\mu g$ \\
2 & -39 & -15 \\
3 & -15 & +5 \\
4 & -59 & -35 \\
5 & -5 & -20 \\
6 & -28 & -21 \\
7 & -55 & -11 \\
8 & -33 & +7 \\
9 & -5 & +14 \\
10 & -71 & 0 \\
11 & -75 & -14 \\
12 & -29 & -20 \\
13 & -21 & -22 \\
14 & -40 & +10 \\
15 & -26 & +13 \\
16 & -61 & -27 \\
17 & -51 & +15 \\
Mean & -36 & +15 \\
& &
\end{tabular}

* Difference means the total phosphate content of the solution incubated with bone from the subject, reduced by the total phosphate content of the solution incubated with standard bone. Where less than $10 \mathrm{mg}$ of bone power was used, the difference was calculated from standard conditions.
TABLE IV

Phosphate "exchange" of bone from two patienls wilh hyperparathyroidism before and after surgical treatment

\begin{tabular}{|c|c|c|c|c|c|}
\hline \multirow[b]{3}{*}{ No. } & \multirow[b]{3}{*}{ Remarks } & \multicolumn{4}{|c|}{ Phosphate exchange } \\
\hline & & \multicolumn{2}{|c|}{$\begin{array}{c}\text { Before } \\
\text { operation }\end{array}$} & \multicolumn{2}{|c|}{$\begin{array}{c}\text { After } \\
\text { operation }\end{array}$} \\
\hline & & Abs. & Rel. & Abs. & Rel. \\
\hline & & $\%$ & $\%$ & $\%$ & $\%$ \\
\hline 1 & $\begin{array}{l}\text { Second biopsy } 3 \text { years } \\
\text { after operation; } \\
\text { patient healthy }\end{array}$ & 44.6 & 140.3 & 29.7 & 106 \\
\hline 15 & $\begin{array}{l}\text { Second biopsy } 1 \text { year } \\
\text { after operation; } \\
\text { patient died of } \\
\text { uremia }\end{array}$ & 39.6 & 136 & 23.8 & 87 \\
\hline
\end{tabular}

phate "exchange" percentage of bone from five patients with hypercalcemia not caused by hyperparathyroidism. The results are given in Table V. In these five cases no increased percentage of exchange was found. All data are within the control group.

\section{Quantitative microradiography}

\section{A. Method}

Bone biopsies were obtained from patients and controls. The bone sample was held in 96 per cent alcohol for 24 hours and dehydrated with absolute alcohol and benzoyl benzoate. It was then imbedded in methyl methacrylate. A copper saw with an inner edge provided with diamond powder (13) was used to make slices $100 \mu$ thick which were ground under water on ground-glass to about $70 \mu$. The width of slices was measured by microscope and ocular micrometer. An $\mathrm{X}$-ray photograph was then made with an Enraf roentgen diffraction apparatus provided with a Philips copper anti-cathode tube with a focal size of $10 \mathrm{~mm}^{2}$ and a mica beryllium window. The filter was $20 \mu$ aluminum. The sample was photographed together with two aluminum

TABLE $V$

Phosphate "exchange" of bone from five patients with hypercalcemia not caused by hyperparathyroidism

\begin{tabular}{|c|c|c|c|c|}
\hline \multirow{2}{*}{$\begin{array}{l}\text { Patient } \\
\text { no. }\end{array}$} & \multirow{2}{*}{ Age } & \multirow[b]{2}{*}{ Diagnosis } & \multicolumn{2}{|c|}{ Phosphate exchange } \\
\hline & & & Abs. & Rel. \\
\hline & yrs & & $\%$ & $\%$ \\
\hline $\begin{array}{l}1 \\
2\end{array}$ & $\begin{array}{l}20 \\
41\end{array}$ & $\begin{array}{l}\text { Sarcoidosis } \\
\text { Vit. D intox.; } \\
\text { idiopathic hypopara- } \\
\text { thyroidism }\end{array}$ & $\begin{array}{l}29.9 \\
20.5\end{array}$ & ${ }_{70}^{118}($ Mean $=96)$ \\
\hline 3 & 51 & $\begin{array}{l}\text { Metastatic mam- } \\
\text { mary cancer }\end{array}$ & 27.6 & 93 \\
\hline 4 & 60 & $\begin{array}{l}\text { Metastatic } \\
\text { bronch. cancer? }\end{array}$ & 29.3 & 107 \\
\hline 5 & 63 & $\begin{array}{l}\text { Metastatic intest. } \\
\text { cancer }\end{array}$ & 25.3 & 94 \\
\hline
\end{tabular}


TABLE VI

Experimental error of quantitative microradiography

\begin{tabular}{|c|c|c|c|c|c|c|}
\hline Patient & Sex & Age & $\begin{array}{l}\text { Site of the iliac } \\
\text { crest biopsy* }\end{array}$ & $\begin{array}{l}\text { Thickness } \\
\text { of bone slice }\end{array}$ & \multicolumn{2}{|c|}{$\mathrm{Al}$ eq. $\dagger$} \\
\hline Gast. & $\mathrm{F}$ & 31 & Left ventral & 68 & $\begin{array}{l}81.6 \\
76.5 \mathrm{Mean}= \\
76.0 \mathrm{SD} \neq= \\
79.8 \mathrm{n} \neq \\
80.5\end{array}$ & $\begin{array}{l}=78.9 \\
=2.5 \\
=5\end{array}$ \\
\hline v.E. & $\mathbf{M}$ & 52 & $\begin{array}{l}\text { Right ventral } \\
\text { Right middle } \\
\text { Right dorsal } \\
\text { Left ventral } \\
\text { Left dorsal }\end{array}$ & $\begin{array}{l}90 \\
80 \\
87.5 \\
90 \\
95\end{array}$ & $\begin{array}{l}92 \\
91.2 \text { Mean } \\
87.4 \mathrm{SD} \\
86.7 \mathrm{n} \\
84.9\end{array}$ & $\begin{array}{l}=88.4 \\
=\quad 3.16 \\
=\quad 5\end{array}$ \\
\hline Zuid. & $\mathrm{M}$ & 87 & $\begin{array}{l}\text { Right ventral } \\
\text { Right dorsal } \\
\text { Left ventral } \\
\text { Left middle } \\
\text { Left dorsal }\end{array}$ & $\begin{array}{l}88 \\
88.5 \\
86.4 \\
81 \\
91\end{array}$ & $\begin{array}{l}88.1 \\
90.5 \mathrm{Mean} \\
87.6 \mathrm{SD} \\
95.6 \mathrm{n} \\
88\end{array}$ & $\begin{array}{l}=90 \\
=3.35 \\
=5\end{array}$ \\
\hline Herm. & $\mathrm{F}$ & 47 & $\begin{array}{l}\text { Right ventral } \\
\text { Right middle } \\
\text { Right dorsal } \\
\text { Ieft ventral } \\
\text { Left dorsal }\end{array}$ & $\begin{array}{l}94 \\
91 \\
81 \\
92 \\
87\end{array}$ & $\begin{array}{l}83 \\
91.1 \text { Mean } \\
89.5 \mathrm{SD} \\
89.3 \mathrm{n} \\
90.4\end{array}$ & $\begin{array}{l}=88.7 \\
=3.20 \\
=5\end{array}$ \\
\hline
\end{tabular}

* Ventral $=1 \frac{1}{2} \mathrm{~cm}$ dorsal of the anterior superior iliac spine; middle $=2 \frac{1}{2} \mathrm{~cm}$ dorsal of the anterior superior iliac spine; dorsal $=3 \frac{1}{2} \mathrm{~cm}$ dorsal of the anterior superior iliac spine.

$\dagger$ Equivalent of $100 \mu$ bone expressed in microns of aluminum ( $\mathrm{sp}$ gr of aluminum $=2.57$ ).

$\ddagger \mathrm{SD}=$ standard deviation; $\mathrm{n}=$ number of observations.

step wedges having 10 steps each, built up of aluminum foil to a thickness of $10 \mu$ and weighing $2.57 \mathrm{mg}$ per $\mathrm{cm}^{2}$ at that thickness. The photographic material was Kodak 649-0 and Kodak M.R. plates. The window of the roentgen tube was set at $25 \mathrm{~cm}$ from the preparation. The pictures were made with $20 \mathrm{kv}$ and $25 \mathrm{ma}$. Exposure times were chosen so that the density, $D\left(D=\log I_{0} / I\right)$, was about 0.4 .

After development of the films microphotometric measurements were made with a self-registering photometer. A light beam with a diameter of $20 \mu$ was used. The galvanometer readings from the X-ray pictures of the bone were converted into equivalent microns of aluminum by means of a curve based on the density caused by the aluminum step wedges. An average with a standard deviation was then calculated from all measurements made on the film, all averages being calculated for a bone thickness of $100 \mu$.

Evaluation of the experimental error. To estimate the size of the experimental error, a single bone sample was measured five times. The results are shown in Table VI. For an average value of $78.9 \mu$ aluminum for $100 \mu$ bone, a standard deviation of 2.5 was found. Next, from each of three patients, five biopsy samples were taken postmortem, three from the left iliac crest and two from the right iliac crest or vice versa. The biopsy samples were taken from an area 1 to $3 \mathrm{~cm}$ dorsal to the anterior superior iliac spine. The results obtained from this material are also shown in Table VI. The data indicate that small variations in the location on the iliac crest where the biopsies were done do not affect the experimental results. It should be noted that the patients here concerned did not have hyperparathyroidism.

It was found that the results obtained were independent of the thickness of the slices. The plastic embedding material, which caused only 1.2 per cent of the absorption of the $\mathrm{X}$-rays in the bone, has hardly any effect on the final result.

\section{B. Results}

Bone tissue from the same 17 patients with hyperparathyroidism and 17 controls described above (Table I) was investigated. The results of the investigation of the bone of the patients and controls are given in Table VII. These data show that there is a highly significant difference between the mineral content of bone from normal individuals and from hyperparathyroid patients (equivalent for $100 \mu$ bone: $84.6 \pm 3.3$ versus $74 \pm 4$; $1<0.001)$. The data for the individuals from both groups are shown graphically in Figure 5 . The $\chi^{2}$ criterion showed that the data from $\mathrm{Pa}$ tients 12,13 and 14 did not significantly differ from the data found in the control group. The 
- Hyperparathyroidism

- Controls

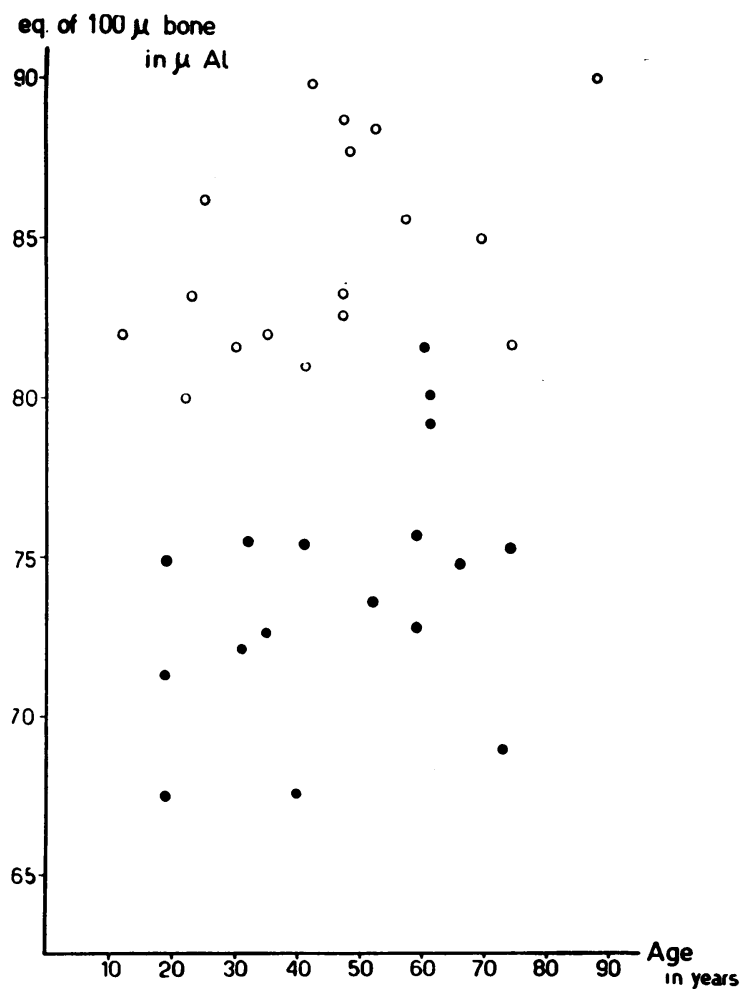

Fig. 5. The Mineral CONTENT OF BONE From 17 PATIENTS WITH HYPERPARATHYROIDISM COMPARED WITH THAT OF CONTROLS. The mineral content is estimated by quantitative microradiography and expressed in the thickness of aluminum foil that gives the same X-ray absorption as $100 \mu$ of bone.

data from the remaining 14 patients can be considered as not belonging to those of the control group.

From the large number of measurements made at different points on each bone sample $( \pm 284$ per sample), the standard deviation from the average found in that sample was calculated (Table VI, column 5). The average standard deviation for 17 patients with hyperparathyroidism was 9.2 , and for the 17 controls, 7.6. This difference is significant at the $\mathrm{p}<0.05$ level.

Figure 6 shows all the measurements made on bone of hyperparathyroid patients and all those on bone from controls, divided into groups of $5 \mu$ aluminum equivalent. The frequency distribution of the groups is shown graphically. The curve for the data from hyperparathyroid patients has a sharp maximum and is shifted to the left in comparison with the curve for the controls.

Samples from two patients (nos. 1 and 15 in Table VII) were measured for mineral content after the patients had recovered from their hyperparathyroidism following the removal of an adenoma of the parathyroid gland. The data from before and after treatment are given in Table VIII.

TABLE VII

Mineral content of bone from 17 patients with hyperparathyroidism and from 17 controls *

\begin{tabular}{|c|c|c|c|c|c|}
\hline \multirow[b]{2}{*}{$\begin{array}{c}\text { Subject } \\
\text { no. }\end{array}$} & \multicolumn{5}{|c|}{ Hyperparathyroidism } \\
\hline & Age & Sex & Mean & SD & $\begin{array}{c}\text { No. of } \\
\text { photo- } \\
\text { metric } \\
\text { measure- } \\
\text { ments }\end{array}$ \\
\hline & yrs & & & & \\
\hline 1 & 19 & M & 67.3 & 6.5 & 465 \\
\hline 2 & 19 & M & 71.2 & 13.3 & 168 \\
\hline 3 & 19 & M & 74.9 & 8.8 & 142 \\
\hline 4 & 31 & M & 72.1 & 8.2 & 217 \\
\hline 5 & 31 & M & 75.5 & 5.3 & 156 \\
\hline 6 & 35 & M & 72.6 & 12.6 & 642 \\
\hline 7 & 40 & $\mathrm{~F}$ & 67.5 & 11.0 & 297 \\
\hline 8 & 41 & $\mathrm{~F}$ & 75.4 & 10.4 & 472 \\
\hline 9 & 52 & $\mathrm{~F}$ & 73.6 & 6.7 & 297 \\
\hline 10 & 59 & $\mathrm{~F}$ & 72.8 & 12.1 & 194 \\
\hline 11 & 59 & $\mathrm{~F}$ & 74.7 & 7.5 & 147 \\
\hline 12 & 60 & $\mathrm{~F}$ & 81.6 & 3.7 & 97 \\
\hline 13 & 61 & M & 79.6 & 13.7 & 224 \\
\hline 14 & 61 & M & 80.1 & 7.6 & 223 \\
\hline 15 & 66 & $\mathrm{~F}$ & 74.8 & 10.5 & 562 \\
\hline 16 & 73 & M & 68.9 & 9.2 & 245 \\
\hline 17 & 74 & $\mathrm{~F}$ & 75.3 & 10.1 & 200 \\
\hline \multirow{3}{*}{$\begin{array}{l}\text { Group } \\
\text { mean } \\
\text { Group SD }\end{array}$} & & & & & \\
\hline & 47 & & $\begin{array}{r}74 \\
4\end{array}$ & 9.2 & 279 \\
\hline & \multicolumn{3}{|c|}{ Controls } & & \\
\hline 1 & & $\mathrm{M}$ & 81.5 & 8.9 & 203 \\
\hline 2 & 22 & M & 80 & $\begin{array}{l}0.9 \\
7.0\end{array}$ & 184 \\
\hline 3 & 23 & M & 83.2 & 7.3 & 375 \\
\hline 4 & 25 & M & 86.2 & 6.1 & 329 \\
\hline 5 & 30 & $\mathrm{~F}$ & 81.6 & 7.1 & 303 \\
\hline 6 & 35 & $\mathbf{M}$ & 82.0 & 9.5 & 187 \\
\hline 7 & 41 & $\mathrm{~F}$ & 81.0 & 7.2 & 279 \\
\hline 8 & 42 & $\mathrm{~F}$ & 89.8 & 8.5 & 217 \\
\hline 9 & 47 & $\mathrm{~F}$ & 83.3 & 9.0 & 186 \\
\hline 10 & 27 & $\mathrm{M}$ & 82.6 & 7.4 & 332 \\
\hline 11 & 47 & M & 88.7 & 4.2 & 251 \\
\hline 12 & 48 & $\mathrm{~F}$ & 87.7 & 8.2 & 859 \\
\hline 13 & 52 & M & 88.4 & 4.1 & 117 \\
\hline 14 & 57 & $\mathrm{~F}$ & 85.6 & 9.0 & 407 \\
\hline 15 & 69 & $\mathrm{M}$ & 85.0 & 7.7 & 310 \\
\hline 16 & 74 & $\mathrm{~F}$ & 81.7 & 8.0 & 274 \\
\hline 17 & 87 & M & 90.0 & 4.1 & 91 \\
\hline Group & & & & & \\
\hline mean & 45 & & 84.6 & 7.6 & 288 \\
\hline & & & 3.3 & & \\
\hline
\end{tabular}

* Values expressed as indicated in legend of Figure 5. 
TABLE VIII

The mineral content of the bone of two patients with hyperparathyroidism before and after surgical treatment*

\begin{tabular}{|c|c|c|c|}
\hline \multirow[b]{2}{*}{ No. } & \multirow[b]{2}{*}{ Remarks } & \multicolumn{2}{|c|}{ Mineral content } \\
\hline & & Pre-op. & Post-op. \\
\hline 1 & $\begin{array}{l}\text { Second biopsy } 3 \text { years } \\
\text { after operation; } \\
\text { patient healthy }\end{array}$ & 67.3 & 80 \\
\hline 15 & $\begin{array}{l}\text { Second biopsy } 1 \text { year } \\
\text { after operation; } \\
\text { patient died of } \\
\text { uremia }\end{array}$ & 74.8 & 78.2 \\
\hline
\end{tabular}

* Mineral content expressed as indicated in legend of Figure 4 .

The bone from both patients had a higher mineral content after the operation, but only in the first case was the difference statistically significant.

Bone samples from five patients with hypercalcemia not caused by hyperparathyroidism were analyzed for mineral content. The results are shown in Table IX. One of these patients, with hypoparathyroidism and vitamin $\mathrm{D}$ intoxication, had a low mineral content, while the other four patients revealed normal values.
TABLE IX

The mineral content of the bone of five patients with hypercalcemia not caused by hyperparathyroidism *

\begin{tabular}{ccll}
\hline $\begin{array}{c}\text { Patient } \\
\text { no. }\end{array}$ & Age & \multicolumn{1}{c}{ Diagnosis } & $\begin{array}{c}\text { Mineral } \\
\text { content }\end{array}$ \\
\hline & yrs & Sarcoidosis & 79.5 \\
2 & 20 & $\begin{array}{l}\text { Vit. D intox. ; } \\
\text { idiopathic hypopara- } \\
\text { thyroidism } \\
\text { Metastatic mam- }\end{array}$ & 74.3 \\
3 & 51 & $\begin{array}{l}\text { Mary cancer } \\
\text { Metastatic bronch. }\end{array}$ & 84.7 \\
5 & 60 & $\begin{array}{l}\text { Cancer? } \\
\text { Metastatic intest. } \\
\text { cancer }\end{array}$ & 83.5 \\
& 63 & Mean & 82
\end{tabular}

* Mineral content is expressed as indicated in legend of Figure 4.

\section{DISCUSSION}

It has been demonstrated that human bone from young individuals contains more water and less minerals than does bone from old individuals (14, 15). Tracer studies with intact experimental animals in vivo have established that the skeleton of young individuals shows greater uptake of bone-

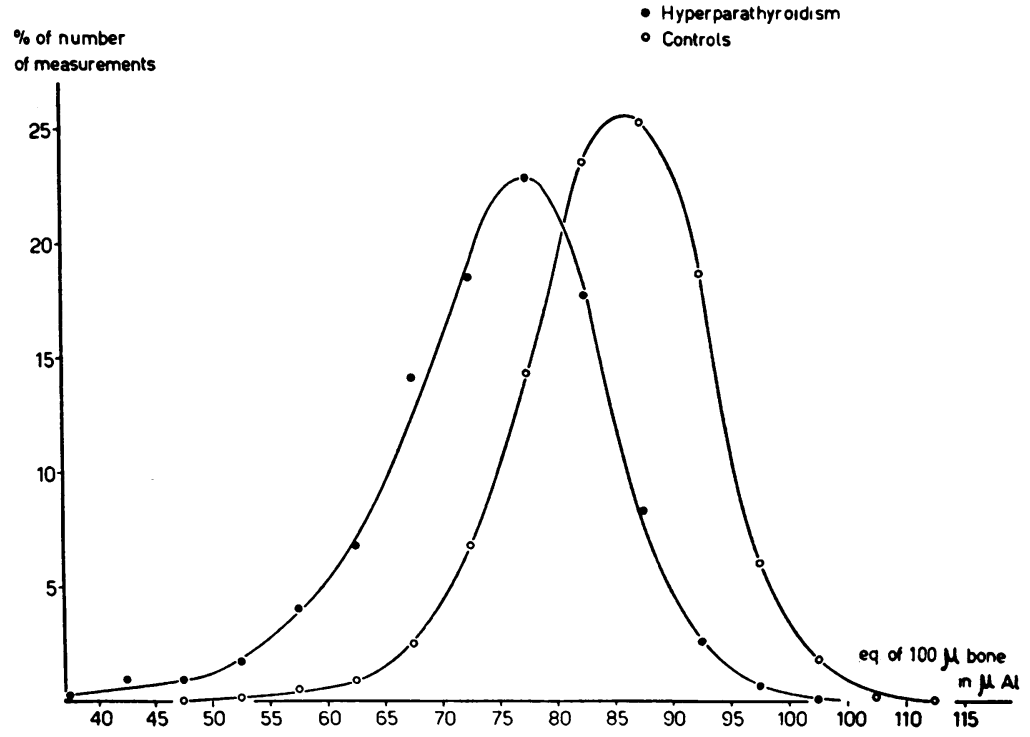

Fig. 6. Distribution of the values of the mineral content of bone IN 4,740 MEASUREMENTS IN SAMPLES FROM 17 PATIENTS WITH HYPERPARATHYROIDISM AND IN 4,900 MEASUREMENTS IN BONE FROM 17 CONTROL INDIviduALs. The mineral content is expressed in the thickness of aluminum foil that gives the same X-ray absorption as $100 \mu$ of bone. In hyperparathyroidism the mean is $74 \mu$, with a standard deviation of 9.2. In the controls the mean is 84.6 , with a standard deviation of 7.6. 


\begin{tabular}{|c|c|c|}
\hline & $\begin{array}{l}\text { BONE DESTRUCTION } \\
\text { BONE FORMATION }\end{array}$ & $\begin{array}{l}\text { DBCREASED LIINGRAI } \\
\text { CONTEST OF BONE } \\
\text { ( Routine X-Ray ) }\end{array}$ \\
\hline $\begin{array}{c}\text { NORUAL } \\
\text { INDI VI DOLI }\end{array}$ & $\stackrel{\longleftrightarrow}{\longrightarrow}$ & \\
\hline $\begin{array}{l}\text { COUPGSSATED } \\
\text { HIPEPABATHOROIDISU }\end{array}$ & $\longrightarrow$ & \\
\hline $\begin{array}{c}\text { DEC OMPBNSATED } \\
\text { HYPRRPARATHIROI DISU }\end{array}$ & $\longleftrightarrow$ & + \\
\hline
\end{tabular}

Fig. 7. Hypothetical explanation of the ABSENCE OF ABNORMALITIES OF THE SKELETON IN HYPERPARATHYROIDISM. seeking isotopes than that of old individuals (16). The crystal size of subperiosteal bone from the human rib was shown to be larger in old individuals than in young ones (17). Investigations have also been done on bone structures of various ages. The mineral content of young structures is lower than that of older structures (18). In the bone of the human fetus mineralization takes place very rapidly in the first five weeks of this process, but after this period the continued rise in mineral content is very slow (19). Comparable results were found for the calcification in callus formation in rabbits; 60 weeks after the beginning of mineralization the maximum had not yet been

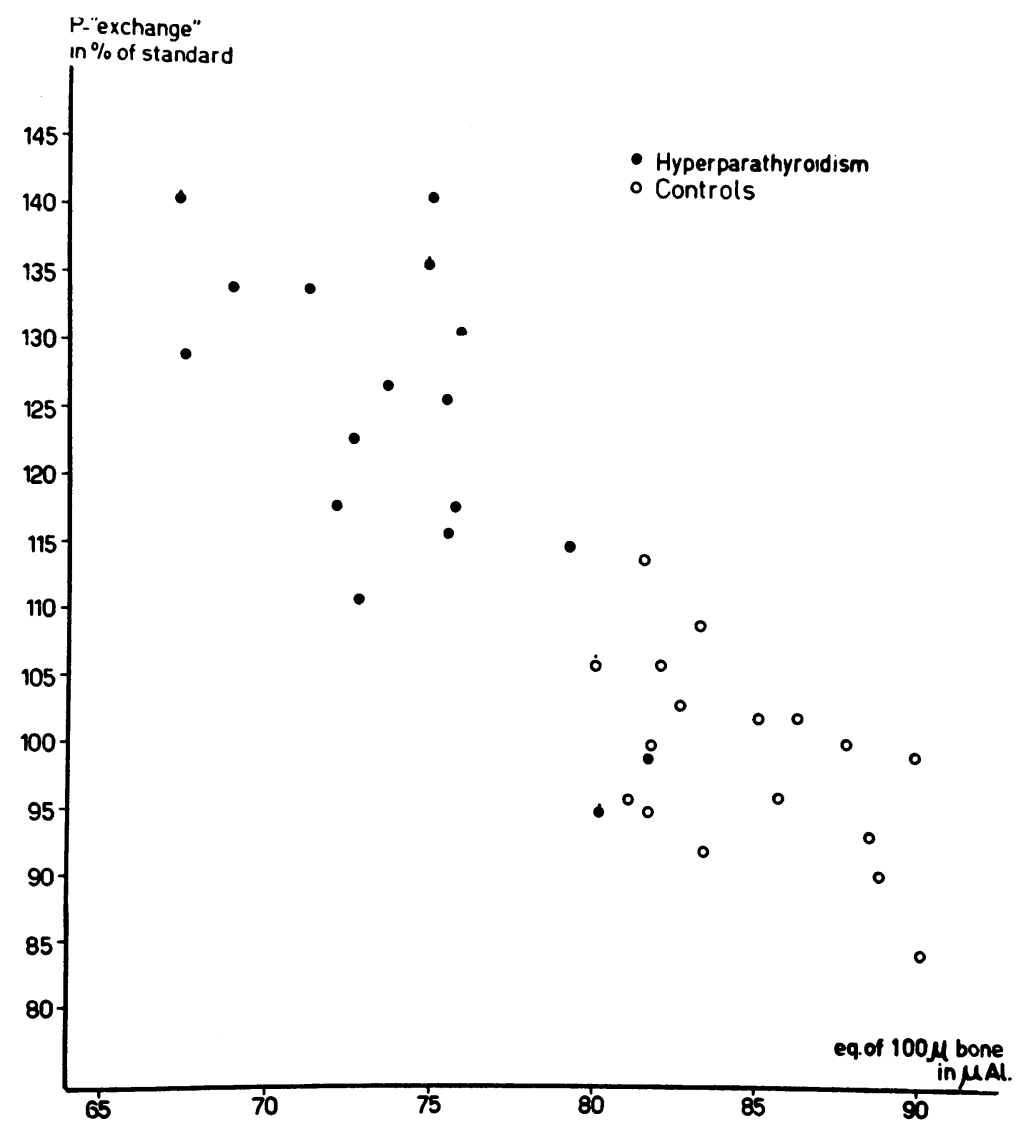

Fig. 8. Negative correlation BEtween the mineral Content and the IN VITRO PHOSPHATE "EXCHANGE" IN BONE FROM 17 PATIENTS With HYPERPARATHYROIDISM AND 17 CONTROLS. The mineral content is expressed in the thickness of aluminum foil that gives the same X-ray absorption as $100 \mu$ of bone. The phosphate "exchange" is expressed as a percentage of a standard. A 61 year old patient, with hyperparathyroidism and cystic lesions in the skull and in a vertebra, had a normal phosphate "exchange" (95 per cent) and a normal mineral content $(80.1 \mu \mathrm{Al})$ of bone from the iliac crest. 
reacheel (20). Thesse data are in agreement with the concept that young bone contains smaller bone crystals than old bone (9).

The results obtained with the phosphate "exchange" experiments with bone from individuals of different ages as described in this paper, indicate that the exchange in young individuals is higher than that in old ones. Since the average crystal size in young individuals is smaller than that in older ones, the crystal surface will be relatively larger, as will the space between the crystals, which is important for diffusion (9). The "exchange" possibilities for ions from the crystal are thus increased.

The investigations of the bone of patients with hyperparathyroidism indicate that the phosphate "exchange" is higher and the mineral content lower than in bone from the controls. Both phenomena can be explained by assuming that, on the average, the crystal size in hyperparathyroid patients is smaller than that in normals. Since there is no indication that the total amount of skeletal bone is increased in hyperparathyroidism (as far as is known only a decrease can be observed), the small crystal size can only be explained by a relative increase in low mineralized bone.

The most obvious explanation for these phenomena is the assumption that new bone formation is accelerated in hyperparathyroidism (Figure 7 ). This explanation is only valid if the characteristics of young bone, as they are known from healthy individuals, are the same in bone from hyperparathyroid patients. The increase in osteoplastic activity found in hyperparathyroidism (21) supports this hypothesis. Alternative explanations, e.g., generalized demineralization or a slowed rate of mineralization can not be exclucled.

The results obtained in this investigation of human bone samples are in agreement with those obtained with qualitative microradiography of bone in experimental animals $(7)$. The results of recent work with radioactive calcium isotopes (22), and with stable strontium (23), in humans with hyperparathyroidism, in which pools are calculated from disappearance curves, are also in agreement with our measurements in bone biopsy specimens.

It is striking that the 61 year old patient, with a mineral content equivalent to $80.1 \mu$ aluminum and a phosphate "exchange" of 95 per ecent in bene from the iliac crest (Figure $\delta$ ), leth normal values, showed roentgenologically and histologically an ostitis fibrosa cystica generalisata in several parts of the skeleton. This patient therefore had a local bone disease which could not be demonstrated in the iliac crest, and shows the reverse of what is shown by most of the other patients in whom no localized bone disease could be demonstrated but in whom there were abnormalities in the bone of the iliac crest.

As was to be expected, a reverse correlation is found between the mineral content of the bone and the readiness to exchange phosphate ions in vitro. The correlation coefficient for the 17 patients with hyperparathyroidism is $-0.69(\mathrm{p}<0.001)$, and for the hyperparathyroid group and the control group together, $-0.62(\mathrm{p}<0.001)$. In Figure 8 the relation between these two investigative methods is shown graphically.

\section{SUMMARY}

1. A phosphate "exchange" test in vitro with bone powder and a $\mathrm{P}^{32}$-labeled phosphate solution was used on human bone powder prepared from biopsy samples from the iliac crest. The results of the phosphate "exchange" experiments are expressed as a percentage of a standard, which had an absolute exchange capacity of 26.8 per cent after 24 hours of incubation.

2. The results of the phosphate "exchange" test in a group of 80 human controls show an inverse correlation between the phosphate "exchange" of the bone and the age of the individual ( $\mathrm{R}=-$ 0.69, $\mathrm{p}<0.001)$. An inverse correlation between phosphate "exchange" of the bone and the age of the individual was also shown in an experiment with rats.

3. The phosphate "exchange" in vitro is greater in bone from patients with hyperparathyroidism than in bone from controls. The relative "exchange" percentages are 123.2 \pm 13.2 and $99 \pm$ 6.9 per cent $(\mathrm{p}<0.001)$.

4. Bone from five patients with hypercalcemia not caused by hyperparathyroidism had an average "exchange" percentage which agreed with that for the control group.

5. A technique of quantitative microradiographic determination of the mineral content of bone ob- 
tained by biopsy from the iliac crest using aluminum foil as a reference standard, is described.

6. The bone of 17 patients with hyperparathyroidism had, on the average, a lower mineral content ( $100 \mu$ bone equals $74 \pm 4 \mu$ aluminum) than that of 17 control individuals $(100 \mu$ bone equals $84.6 \pm 3.3 \mu$ aluminum; $\mathrm{p}<0.001)$.

7. Five patients with hypercalcemia not due to hyperparathyroidism had, on the average, a normal mineral content of bone (100 $\mu$ equals $82 \mu$ aluminum).

8. There is a significant correlation between the mineral content of the bone and the phosphate "exchange" percentage $(\mathrm{R}=-0.62, \mathrm{p}<0.001)$.

9. Both the high phosphate "exchange" of the bone from patients with hyperparathyroidism and its low mineral content can be explained by assuming an increased bone production in compensation for the increased osteoblastic bone destruction.

\section{ACKNOWLEDGMENTS}

Grateful acknowledgment is made to Professor A. Querido and to Dr. A. A. H. Kassenaar for their helpful suggestions and criticisms in the course of this study. The author also wishes to thank Miss M. A. Janssen for her technical assistance and Mrs. C. de Vries-van Bilderbeek for her help with the preparation of the manuscript.

\section{REFERENCES}

1. von Recklinghausen, F. D. Die fibröse oder deformierende Ostitis, die Osteomalacie und die oesteoplastische Carcinose in ihren gegenseitigen Beziehungen in Festschrift fur Rudolf Virchow zu seinem 71 Geburtstage. Berlin, Reimer, 1891.

2. Albright, F., Sulkowitch, H. W., and Bloomberg, E. Further experience in the diagnosis of hyperparathyroidism. Including a discussion of cases with a minimal degree of hyperparathyroidism. Amer. J. med. Sci. 1937, 193, 800.

3. Black, B. M., and Zimmer, J. F. Hyperparathyroidism, with particular reference to treatment: Review of 207 proved cases. A. M. A. Arch. Surg. 1956, 72, 830.

4. Collip, J. B., Pugsley, L. I., Selye, H., and Thomson, D. L. Observations concerning the mechanism of parathyroid hormone action. Brit. J. exp. Path. 1934, 15, 335.

5. Barnicot, N. A. Local action of parathyroid and other tissues on bone in intracerebral grafts. J. Anat. (Lond.) 1948, 82, 233.

6. Gaillard, P. J. Parathyroid gland and bone in vitro. Schweiz. med. Wschr. 1957, 87, 447.

7. Engfeldt, B., and Zetterström, R. Biophysical and chemical investigation on bone tissue in experimental hyperparathyroidism. Endocrinology 1954, 54, 506.

8. Engfeldt, B., and Hjertquist, S. O. Biophysical studies on bone tissue. $\mathrm{X}$. The in vivo and in vitro uptake of radioactive isotopes and ionic exchange reactions in bone tissue. Acta pathol. microbiol. scand. 1954, 35, 205.

9. Neuman, W. F., and Neuman, M. W. The Chemical Dynamics of Bone Mineral. Chicago, University of Chicago Press, 1958.

10. Engström, A. Quantiative micro- and histochemical elementary analysis by roentgen absorption spectrography. Acta radiol. (Stockh.) 1946, suppl. 63.

11. Sacker, L. S., and Nordin, B. E. C. A simple bone biopsy needle. Lancet 1954, 1, 347.

12. Smeenk, D. Investigation of bone samples taken by biopsy from patients with hyperparathyroidism by means of microradiography and a phosphate exchange test in vitro. Thesis, University of Leiden, 1958.

13. Jansen, M. T. The preparation of thin ground sections of enamel and dentine. T. Tandheelk. 1951, $58,342$.

14. Vogt, J. H. Investigations on the bone chemistry of man. I. Ash content of spongy substance of iliac crest. Acta med. scand. 1949, 135, 221.

15. Vogt, J. H., and Tфnsager, A. Investigations of the bone chemistry of man II. Phosphatase, calcium, phosphorus and nitrogen in substantia spongiosa cristae ilei. Acta med. scand. 1949, 135, 231.

16. Neuman, W. F., and Neuman, M. W. The nature of the mineral phase of bone. Chem. Rev. 1953, 53, 1.

17. Robinson, R. A., and Watson, M. L. Crystal-collagen relationships in bone as observed in the electron microscope. III. Crystal and collagen morphology as a function of age. Ann. N. Y. Acad. Sci. 1955, 60, 596.

18. Amprino, R., and Engström, A. Studies on x-ray absorption and diffraction of bone tissue. Acta anat. (Basel) 1952, 15, 1.

19. Wallgren, G. Biophysical analyses of the formation and structure of human fetal bone. A microradiographic and $\mathrm{x}$-ray crystallographic study. Acta paediat. (Uppsala) 1957, 46, suppl. 113.

20. Holmstrand, K. Biophysical investigations of bone transplants and bone implants. An experimental study. Acta orthop. scand. 1957, suppl. 26.

21. McLean, F. C. Hyperparathyroidism and bone disease in The Biochemistry and Physiology of Bone, G. H. Bourne, Ed. New York, Academic Press, 1956, p. 721.

22. Bauer, G. C., Carlsson, A., and Lindquist, B. Use of isotopes in clinical studies of skeletal metabolism. Strahlentherapie 1958, 38, 25.

23. Harrison, M., and Fraser, R. Hyperparathyroidism. Proc. roy. Soc. Med. 1959, 52, 255. 